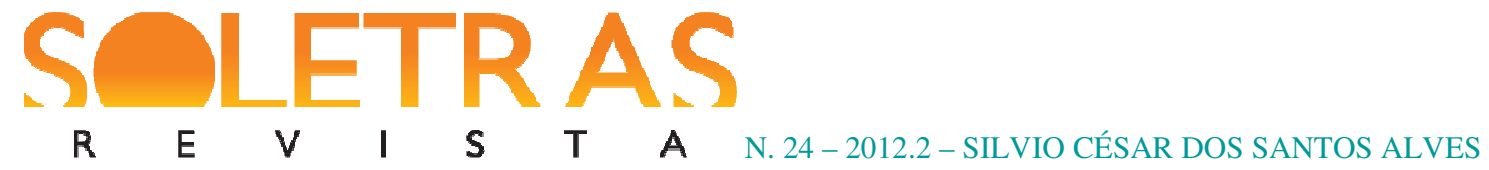

\title{
Arautos da modernidade: Cesário Verde, Antero de Quental, Eça de Queirós e a crise intelectual finissecular em Portugal
}

Silvio César dos Santos Alves ${ }^{1}$

\begin{abstract}
Resumo: Este trabalho tem como objetivo apresentar alguns aspectos da relação de Cesário Verde, Antero de Quental, Eça de Queirós e suas respectivas obras, relacionando-os à crise intelectual do fim do século XIX. Tentamos apontar em que medida esses autores foram ou não capazes de superar o fim das certezas que orientavam a cultura ocidental até meados desse século. Sobretudo, procuramos demonstrar, nesses autores, procedimentos estéticos que anunciam novos valores que mais tarde seriam identificados com a modernidade portuguesa.
\end{abstract}

Palavras-chave: Literatura Portuguesa. Crise intelectual. Século XIX.

Em uma comunicação intitulada Gênese e descendência da poesia de Cesário Verde, Joel Serrão cita várias referências de Fernando Pessoa e seus heterônimos sobre a influência recebida da precursora modernidade de Cesário Verde. Inversamente, Serrão também propõe uma série de autores - com a exceção de Baudelaire, todos contemporâneos do poeta oitocentista - que, provavelmente, teriam exercido alguma influência sobre a poesia de Cesário, especificamente em relação à forma como este percebia o real. Segundo esse autor, uma tal consonância estética

[...] não acontece por acaso e por factos de natureza puramente idiossincrásica relativamente aos poetas, acontece num contexto cultural deste tempo que medeia entre aquilo que significou a geração de Coimbra e o que significa, pelos fins do século, a proclamação de Zaratustra: de que Deus morrera e que o Superhomem nascera. Ou seja, trata-se na verdade de uma crise fundamental na evolução da história ocidental e sobretudo da relação do homem com o sagrado. Com o sagrado que está ligado às origens de toda a civilização dita ocidental (SERRÃO, 1993, p. 88).

Desse trecho do breve, mas importante, texto de Serrão que acabamos de mencionar, destacamos quatro pontos que consideramos fundamentais: a delimitação temporal do

\footnotetext{
${ }^{1}$ Doutorando em Literatura Comparada do Programa de Pós-graduação em Letras da Universidade do Estado do Rio de Janeiro. Mestre em Letras (Literatura Portuguesa) pela Universidade do Estado do Rio de Janeiro. É autor do conto "Mudança" (2003), indicado ao "Prêmio Literário Nossa gente, Nossas Letras. Homenagem a Graciliano Ramos", organizado pela Biblioteca Nacional e pela Editora Record, pela qual foi publicado. Recebeu, em 2009, da Fundação Eça de Queiroz e do Instituto Camões, bolsa para o XI Curso Internacional de Verão "Eça: a modernidade e o modernismo" (2009), organizado pela referida fundação, em Santa Cruz do Douro ("Tormes"), Portugal. E-mail: silviohaiti@ hotmail.com.
} 


\section{$\begin{array}{llllllll}R & \text { E } & \text { V } & \text { I } & \text { S } & \text { T } & \text { A } & \text { N. 24-2012.2-SILVIO CÉSAR DOS SANTOS ALVES }\end{array}$}

contexto cultural em que acontece a produção poética de Cesário numa perspectiva europeísta - entre a ascensão intelectual da chamada "Geração de 70" e os discursos do Zaratustra, de Nietzsche; a qualificação desse contexto como uma "crise fundamental" da "evolução da história humana ocidental" na segunda metade do século XIX, "sobretudo da relação do homem [...] com o sagrado que está ligado às origens de toda a civilização dita ocidental"; a hipótese, segundo a qual, autores como Vítor Hugo, Baudelaire, João de Deus, Antero de Quental, Eça de Queirós, Guerra Junqueiro, Guilherme de Azevedo, Gomes Leal e Guilherme Braga poderiam ter tido alguma influência na gênese da poesia de Cesário Verde - assim como ele próprio tivera na obra de Fernando Pessoa e seus heterônimos (como estes confessaram em diversos dos seus textos) - em virtude dessa mesma crise, e não devido ao simples acaso ou a "factos de natureza puramente idiossincrásica"; e a visão da poesia de Cesário como representativa de uma fase de transição entre o que a Civilização Ocidental era e o que ela viria a ser após essa crise.

No tocante aos efeitos intelectuais sincrônicos e atópicos dessa crise referida por Serrão, parece-nos ter ocorrido aquele espantoso laço de unidade que, segundo Ulrich Weisstein, em "Literatura comparada: definição", "é possível encontrar-se” (...) “dentro de uma única civilização" (WEISSTEIN, 1994, p. 312). Parece-nos também ser nesse sentido que, n'O primeiro Fradique Mendes, Joel Serrão chama a atenção para as "ondas de fundo" presentes na história cultural e das mentalidades que justificariam um nietzschiano anúncio da "morte de Deus" já na poesia do jovem Antero de Quental. Serrão, porém, argumenta

[...] que se não está a sugerir que as vivências culturais portuguesas sintonizavam, ou sequer podiam sintonizar, com as inquietações filosóficas mais estruturadas e estruturantes da metafísica de além-Pirinéus. Tãosomente se crê que é lícito imaginar-se, em termos de história cultural e das mentalidades, que há ondas de fundo - ideias, vivências, atitudes -, e que algumas delas se espraiaram até à finisterra portuguesa (SERRÃO, 1985, p. 129).

Para Pedro Eiras - em Do dionisismo dândi: entre Fradique e Zaratustra - o Fradique "proto-heterónimo colectivo de 1868-1869, hiper-romântico, conhece o dionisíaco quebrar das estátuas, mas desconhece o que poderá substituir os ídolos” (EIRAS, 2004, p. 104). Arriscamo-nos a dizer o mesmo em relação a Cesário. No entanto, talvez o problema em questão não tenha sido apenas o desconhecimento do que poderia substituir os antigos ídolos, mas a incapacidade de assumir a responsabilidade pela derrocada destes, de suportar suas 


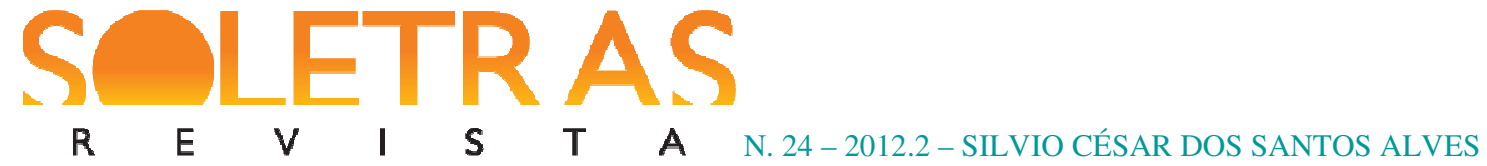

consequências.

Na comunicação a que já aludimos, Serrão levanta a possibilidade de Antero ter estado nos horizontes culturais de Cesário Verde em virtude das experiências do satanismo fradiquiano de 1869 (SERRÃO, 1993, p. 84). Segundo Batalha Reis, que, juntamente com Antero e Eça, deu origem ao heterônimo coletivo, a invenção de Fradique passava pela criação de "uma filosofia cujos ideais fossem diametralmente opostos aos ideais geralmente aceites" (BATALHA REIS, 1896, p. 461). Como afirma o próprio Antero, na introdução que faz às poesias fradiquianas publicadas no Primeiro de Janeiro, a 5 de Dezembro de 1869, o que vemos nos versos do primeiro Fradique é "a poesia cantando, sobre as ruínas da consciência moderna, um réquiem e um dies irae fatal e desolador". Questionando-se sobre a “missão da poesia" de seu tempo, Antero pergunta-se se "o seu ideal, isto é, a sua lei suprema" não seria, "pelo contrário, consolar, moralizar, apontar o belo espiritual, a esperança e a crença". No entanto, ao findar o texto, Antero prevê para Fradique "um grande futuro" e, para sua época, "um grande poeta".

Cleonice Berardinelli, em "Cesário entre Fradique e Sá-Carneiro”, referindo-se aos versos do Fradique de 69, pergunta-se: "o que há neles que anuncie Cesário ou em que Cesário se tenha inspirado" (BERARDINELLI, 1992, p. 12). Ela mesma ensaia uma resposta dizendo que "de ruas fala Cesário, em Lisboa; Fradique, em Lisboa e Paris, descreve a rua, o Boulevard; privilegiam ambos a hora intermédia do cair da tarde" (BERARDINELLI, 1992, p. 14). Para a autora, entretanto, se a crítica que ressuma dos poemas anterianos de Fradique "é quase exclusivamente ética, feita por alguém que se confessa, ao fim, triste, porque 'filho da Utopia' e primo do Ideal” (BERARDINELLI, 1992, p. 15); “o que ressalta e é novo em Cesário é a crítica social que o faz lançar uma luz especial sobre os proletários”. A sua conclusão é que "é muito mais profunda a reflexão de Cesário sobre a cidade" e que, nos seus poemas, "o que se desprende não é a voluptuosidade", como no satanismo de Fradique, "mas a Dor (com maiúscula também)" (BERARDINELLI, 1992, p. 16).

Há que se reservar alguma atenção para o fato de que, quanto a Cesário, estamos falando de uma existência real, um poeta que se arrisca no mundo com seus versos. $\mathrm{O}$ Fradique de 69 também é um poeta, mas é, também, um artifício. Cleonice Berardinelli define com clareza e simplicidade a existência heteronímica de Fradique:

Fradique é feito da mesma substância de que se fizeram Alberto Caeiro, Álvaro de Campos ou Ricardo Reis; é, ele também, produto da imaginação, 


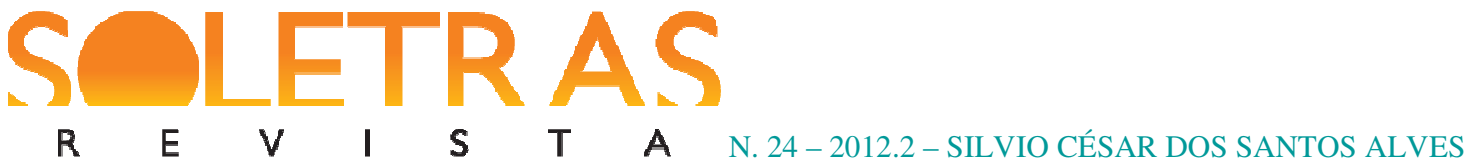

heteronímico, como afirma Pedro da Silveira. A diferença mais visível entre eles está em que um único Fernando Pessoa "deu à luz" vários autores, enquanto que foram pelo menos três - Eça, Antero e Batalha Reis - os criadores de só um Fradique (BERARDINELLI, 1992, p. 12).

No fundo, Fradique é feito, também, da mesma substância com que seria feito o Zaratustra de Nietzsche. Apesar deste não ser um heterônimo, mas um personagem, os dois têm funções parecidas. Em suas existências ficcionais, superam desafios existenciais que seus autores ainda não estavam ou que, talvez, nunca estivessem em condições de superar. Fato a considerar é que, dos três criadores de Fradique, Antero é o único que assume algumas das poesias desse heterônimo como suas, sendo estas publicadas posteriormente sob o seu próprio nome. Batalha Reis, um dos pais da criatura, reconhece que não se sabe ao certo o quanto do verdadeiro Antero estava naquelas poesias que se faziam passar como de Fradique.

Nas Odes modernas, que Antero publica pela primeira vez em 1865, o eu poético, se apresentando como um "escravo, sem pão, lar nem cidade" (QUENTAL, 1865, p. 18), já havia afirmado: "Deos - não pode durar mais que alguns annos!" (QUENTAL, 1865, p. 11). Porém, se a versão nietzschiana de Zoroastro decretará que "Deus morreu" e anunciará o que virá "além do homem", o Antero das "Odes" - que diz "ver os velhos ídolos partidos" e "verse só no mundo e como errante...", "perdida a fé antiga, e ainda obscuros/o Deus e os cultos novos!" (QUENTAL, 1865, p. 139) que poderiam substituir as antigas "verdades, as bíblias, as certezas" (QUENTAL, 1865, p. 11) -, ainda que não queira "perguntar aos Zoroastros" (QUENTAL, 1865, p. 36) onde buscar a resposta para a pergunta sobre o que deve suceder os antigos deuses, afirma que é "no céu incorruptível da Consciência" que "se revela aos homens e às nações", "a Ideia, o sumo Bem, o Verbo, a Essência",2 (QUENTAL, 2001, p. 365), parecendo acreditar, com Hegel, que “L'Idée... c'est Dieu!” (QUENTAL, 1965, p. 6) - como consta na epígrafe da "Parte Primeira" da primeira edição das Odes Modernas. Segundo Fernando Catroga,

\footnotetext{
Antero era mais irmão de Cristo do que primo de Zaratustra. A vitória sobre a crise da civilização ocidental não passava pela negação da metafísica e de Cristo, como em Nietzsche; ao contrário, não estava para além do bem e do mal, requeria a reinvenção e a conciliação da lição cristã com os ensinamentos da "ciência da realidade", e apelava a uma superação que também pretendia conservar a herança da história (CATROGA, 2001, p. 104).
}

\footnotetext{
${ }^{2}$ Esses últimos fragmentos estão contidos na seção VIII, a última do poema "A Ideia". Esse poema foi publicado na primeira edição das Odes Modernas, em 1865, sem essa última seção, que só apareceu na segunda edição, publicada em 1875, embora tenha sido escrita entre os anos de 1864 e 1871.
} 


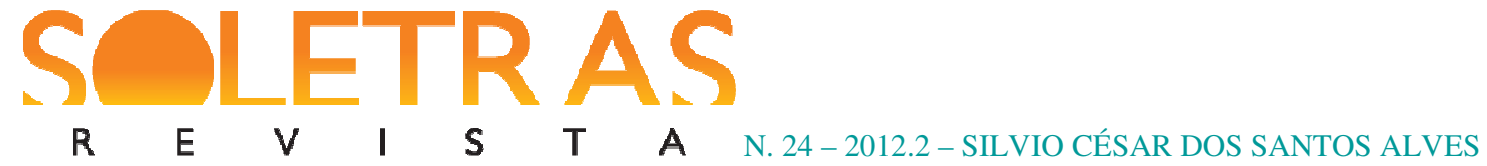

Retomando a célebre distinção, que António Sérgio, na Nota preliminar aos Sonetos, faz das tendências governantes da poesia anteriana, entre um Antero "luminoso" e um Antero "noturno", pode dizer-se que, nas Odes Modernas, tem voz predominante um sujeito poético

[...] que se concentra e libra na embriaguez de alvorada do entendimento claro, no tónico atractivo do resplendor do Sol, no autodomínio, na consciência plena; alguém que se eleva e que se guia sempre pelo anseio viril de estruturação interna, de rigor diáfano do pensamento, de arquitectura sólida do caráter. É um voo másculo, é um hino à luz; é o Antero filósofo e reformador social; é o Antero apóstolo e anunciador do futuro, o servidor da Justiça, o batalhador do Bem (SÉRGIO, 1962, p. XVIII-XXVIII).

Confirmando mesmo a tese de Sérgio, sabemos que, em alguns pontos das Odes Modernas, é possível perceber que essa tendência à "reinvenção" e à "conciliação da lição cristã com os ensinamentos da "ciência da realidade" não é tão forte a ponto de obnubilar algum traço do ceticismo remanescente dos primeiros sonetos de Antero e que estará na base, tanto do satanismo fradiquiano como na do misticismo apologético da morte do Antero maduro. Como se sabe, o otimismo de Antero e o sentido social que ele atribui à poesia não duraram muito, e seus poemas passaram a ser apenas o reflexo metafísico do mais extremo pessimismo - muitas vezes dissimulado por um otimismo místico -, a partir de 1874. Entretanto, é ainda o Antero "filósofo e reformador social", "apóstolo e anunciador do futuro", "servidor da Justiça" e "batalhador do Bem" quem proferirá, nas "Conferências do Casino", a célebre conferência "Causas da decadência dos povos peninsulares nos últimos três séculos". Para a "geração de Coimbra", que, no início de suas atividades intelectuais, tinha os olhos fitos no "claro sol, amigo dos heróis", essa conferência surgiria como uma espécie de "hino à luz", a redenção dos homens órfãos da antiga luz divina: a luz da "Razão", da "Justiça" e da "Verdade".

Em seus Estudos de literatura brasileira e portuguesa - na breve, porém muito apropriada referência que faz à conferência de Antero -, Paulo Franchetti afirma que, "a longo prazo, foi esse um dos textos que teve mais repercussões na moderna cultura portuguesa e pode-se ver nele uma síntese ideológica da visão histórica do grupo todo" (refere-se à geração de Antero) (FRANCHETTI, 2007, p. 137). De acordo com o entendimento desse autor,

Tão importante foi essa conferência, que se pode mesmo dizer que a obra 


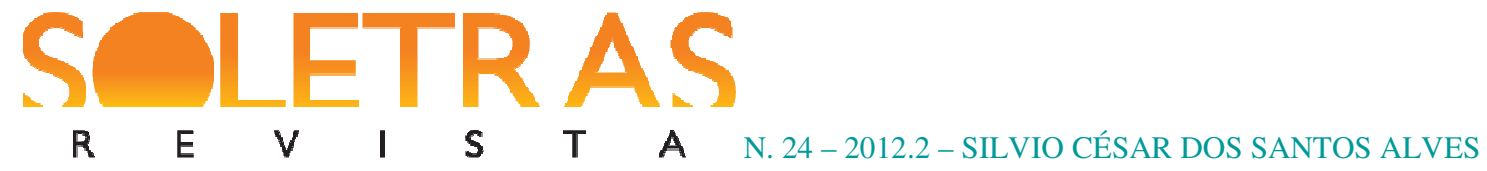

cultural da Geração de 70 consiste no desenvolvimento das teses e propostas aí apresentadas, e que, cada um a seu modo, os companheiros de Antero tratarão de descobrir e apresentar caminhos para reverter a decadência profunda que, de seu ponto de vista, caracteriza aquele momento da vida nacional (FRANCHETTI, 2007, 137).

Concordamos com Franchetti, relativamente à ascendência que as "Causas da decadência dos povos peninsulares nos últimos três séculos" tiveram sobre os companheiros de geração de Antero. No entanto, o desenvolvimento das teses e propostas dessa conferência não deve ser encarado como um processo de tensão ascendente, como parece entender Franchetti. De acordo com Isabel Pires de Lima, em "Os vencidos da vida: a consciência desistente", "as Conferências do Casino podem considerar-se o ponto culminante de uma fase contestatária e ideologicamente optimista da Geração de 70” (LIMA, 1990, p. 331). Para Alberto Ferreira, em Estudos de cultura portuguesa do século XIX, aquela revolução pregada pelos homens de 70 "foi um sonho, uma palavra mítica”. Porém, esse mesmo autor faz a ressalva de que, "ao longo dos anos a palavra Revolução vai-se degradando ou enchendo de ambiguidades" (FERREIRA, 1980, p. 66). Mais do que a crença na capacidade da revolução para garantir o sonhado bem-estar universal, parece-nos que o próprio otimismo gerador dessa crença é que vai sendo rapidamente rasurado por seus principais difusores.

Na novela $O$ Mandarim, publicada por Eça de Queirós, em 1880, é visível o início de certo recuo ideológico em relação a posições estéticas e ideológicas assumidas por sua geração nas "Conferências do Casino". Na $3^{\text {a }}$ edição d' O crime do padre Amaro - a segunda em livro $^{3}$-, publicada nesse mesmo ano de 1880, já é possível notar que, ao lado da irônica crítica à "burguesia entorpecida", há também uma constatação da puerilidade idealista daquela "mocidade, envernizada de literatura" - mas também de filosofia -, da qual ele próprio fizera parte, e que, no ano de 1871, havia se proposto a destruir, não apenas "num folhetim", mas também em uma série de conferências, a sociedade portuguesa de seu tempo e suas tradições enraizadas há vários séculos. Porém, não se pode negar que $O$ crime do padre Amaro faz parte, ainda, do projeto estético que Eça anunciara naquela sua conferência.

\footnotetext{
${ }^{3}$ O crime do padre Amaro foi publicado inicialmente na Revista Ocidental, entre 15 de fevereiro e 15 de maio de 1875. Esta primeira versão foi drasticamente recusada por Eça. Em 1876, saiu a primeira edição em livro (segunda versão). E em 1880 saiu a segunda edição em livro (terceira versão da obra), que "é quase o dobro da anterior; tendo sido revista em Bristol, de outubro de 1878 a outubro de 1879". Em 12 de dezembro de 1878, Eça escreveu ao seu editor: "O Pe. Amaro é um romance novo. Pode sem receio anunciá-lo como tal: mais, é um romance bien autrement interessante que o $\mathrm{P}^{\circ}$. Basílio." A terceira edição em livro é de 1889: "com variantes relativamente à anterior, não foi revista por Eça, segundo a opinião de Helena Cidade Moura" (Ver MATOS, 1988. p. 242-244).
} 


\section{$\begin{array}{llllllll}R & \text { E } & \text { V } & \text { I } & \text { S } & \text { T } & \text { A } & \text { N. 24-2012.2-SILVIO CÉSAR DOS SANTOS ALVES }\end{array}$}

A cena final do último capítulo dessa obra transcorre no ano de 1871, o mesmo ano das "Conferências" e da Comuna parisiense. Ela termina com uma pequena reunião entre o "homem de Estado", o padre Amaro e o cônego Dias - os dois "homens de religião" que compunham a cena na primeira edição - sob a imagem simbólica da estátua de Camões, que também não estava presente na edição da Revista Ocidental:

E o homem de Estado, os dois homens de religião, todos três em linha, junto às grades do monumento, gozavam de cabeça alta esta certeza gloriosa da grandeza do seu país - ali ao pé daquele pedestal, sob o frio olhar de bronze do velho poeta, ereto e nobre, com os seus largos ombros de cavaleiro forte, a epopeia sobre o coração, a espada firme, cercado dos cronistas e dos poetas heróicos da antiga pátria - pátria para sempre passada, memória quase perdida! (QUEIRÓS, s/db, p. 392-3).

Eça publica a $3^{\text {a }}$ edição d'O crime do padre Amaro em 1880, ano das comemorações do terceiro centenário da morte de Camões, que Antero e Oliveira Martins tanto criticaram. Referindo-se e essa obra, Carlos Reis, em Estudos Queirosianos: ensaios sobre Eça de Queirós e a sua obra, diz o seguinte:

O final (final, aliás, muito elaborado) d'O crime do Padre Amaro constituíra uma breve incursão pela História e pelas virtualidades simbólicas: não tem outro sentido a inclusão, na terceira versão do romance, da estátua de Camões, na última fase e quase patética página do romance; uma inclusão que se projecta sobre um contexto favorável ao aproveitamento simbólico e crítico do poeta épico: o romance é publicado no ano em que se celebra o terceiro centenário da morte de Camões (REIS, 1999, p. 161).

A presença da estátua de Camões, e a menção à sua epopeia não se devem ao acaso. Como afirma Reis, ela é simbólica. Não há ironia em sua descrição. A estátua é descrita com realismo - diríamos, até mesmo, com simpatia. É o Camões de Garrett que vemos surgir, ou, pelo menos, a imagem de Camões que Garrett legara aos portugueses. Atentemos para o que Eça diz: "antiga pátria - pátria para sempre passada, memória quase perdida" (QUEIRÓS, s/db, p. 393). Aqui se constata a ideia de decadência da pátria que fundamentara toda a ação pública e intelectual de sua geração, mas podemos perceber, também, um desalento pela memória que se perdia. Que memória era essa?

A posição de Eça sobre os valores daquela sociedade aparece através da descrição de Lisboa que o narrador contrapõe ao otimismo cego do conde de Ribamar, que vê na cidade sob seus olhos apenas "paz", "animação" e "prosperidade". A avaliação que esse personagem 


\section{$\begin{array}{llllllll}\text { R } & \text { E } & \text { V } & \text { I } & \text { S } & \text { T } & \text { A } & \text { N. 24-2012.2-SILVIO CÉSAR DOS SANTOS ALVES }\end{array}$}

faz da capital do Reino comprova que a memória representada pela epopeia trazida ao peito pelo poeta estaria mesmo perdida, não fosse ele, o próprio narrador, a preservá-la e a representá-la com sua irônica avaliação do presente. A imagem de Lisboa que ele nos apresenta na última cena dessa obra é o resultado do confronto entre o estado dessa cidade no tempo da narrativa e o mítico passado cantado pelo poeta da estátua. Por trás de uma fina ironia, o que aparece é a completa decadência. Não se pode perder de vista o fim moralizante desse confronto entre a História e o presente. Publicado cerca de nove anos depois, esse capítulo do primeiro romance de Eça não deixa de ser, também, uma síntese ilustrativa dos principais pontos da conferência de Antero, embora este tenha visto na epopeia de Camões apenas o canto de glórias que empobreciam os portugueses, ou seja, uma apologia daquilo que representava sua própria decadência. $\mathrm{O}$ mesmo fito moralizante que aparece na cena final d' $O$ crime do padre Amaro estará presente também, oito anos à frente, num trecho do final d'Os Maias, passado no ano de 1887:

Estavam no Loreto; e Carlos parara, olhando, reentrando na intimidade daquelle velho coração da capital. Nada mudara. A mesma sentinela sonolenta rondava em torno à estatua triste de Camões. Os mesmos reposteiros vermelhos, com brasões eclesiásticos, pendiam nas portas das duas igrejas. O Hotel Alliance conservava o mesmo ar mudo e deserto. Um lindo sol dourava o lajedo; batedores de chapéu à faia fustigavam as pilecas; três varinas, de canastra à cabeça, meneavam os quadris, fortes e ágeis na plena luz. A uma esquina, vadios em farrapos fumavam; e na esquina defronte, na Havanesa, fumavam também outros vadios, de sobrecasaca, politicando.

- Isto é horrível quando se vem de fora! - exclamou Carlos. - Não é a cidade, é a gente. Uma gente feíssima, encardida, molenga, reles, amarelada, acabrunhada!... (QUEIRÓS, 2000, p. 480).

Agora, não temos mais a referência ao "o frio olhar de bronze do velho poeta, ereto e nobre, com os seus largos ombros de cavaleiro forte", nem à "epopeia" que ele traz "sobre o coração", nem à sua "espada firme", nem aos "cronistas" e aos "poetas heroicos da antiga pátria". O narrador apenas menciona a "a estátua triste de Camões". Não obstante essa nova tonalidade da referência ao poeta quinhentista, para Carlos Reis, o final desse romance "de novo enuncia (e aprofunda) um discurso de propensão simbólica e de referência histórica" (REIS, 1999, p. 161). De certa forma, dezessete anos depois do "Casino", e oito d'O crime do padre Amaro, a conferência de Antero é retomada novamente por Eça nessa cena. Mas não podemos dizer que, com essa nova referência a Camões, Eça tenha tido o mesmo objetivo moralizante da última cena do romance de 1880. A tonalidade da referência já não é tão 


\section{$\begin{array}{llllllll}\text { R } & \text { E } & \text { V } & \text { I } & \text { S } & \text { T } & \text { A } & \text { N. 24-2012.2-SILVIO CÉSAR DOS SANTOS ALVES }\end{array}$}

cristalina, mas essencialmente ambígua.

É também em 1880, por ocasião das comemorações do tricentenário da morte de Camões que, no dia 10 de junho, Cesário Verde publica o poema "O sentimento dum Ocidental". Nesse poema, a estátua de Camões aparece "num recinto público e vulgar/Com bancos de namoro e exíguas pimenteiras", e apesar de ser descrito como "Brônzeo, monumental, de proporções guerreiras", o arremate da estrofe revela-nos a tonalidade de decadência que Cesário pretendeu dar à referência: "Um épico doutrora ascende, num pilar!" (VERDE, 2003, p. 144). Jorge Fernandes Silveira, no ensaio "Camões, Cesário Verde e o coro", afirma que "o próprio vaticínio de Camões de ser esquecido pela 'gente surda e endurecida' encontra nos versos de Cesário a sua terrível confirmação" (SILVEIRA, 19791980, p. 79-80). Segundo David Mourão-Ferreira, no artigo "Cesário e Camões: uma leitura complementar de "O sentimento dum ocidental", a "monumentalidade" com que Cesário nos apresenta a brônzea figura de Camões

\footnotetext{
Vem apenas das "proporções guerreiras" com que no bronze o fixaram e não da dimensão poética da própria obra. Quanto a isto, ele é somente "um épico" [...] e, para cúmulo, "um épico doutrora". Bom será pois que se quede lá no século em que viveu e que não venha competir com quem - o próprio Cesário - três séculos depois vai tratando de erguer a sua obra ou de ascender, assim, no céu poético da mesma língua. No que respeita ao "épico doutrora", é só em termos de escultórica representação que ele ainda "ascende, num pilar" (MOURÃO-FERREIRA, 1995, p. 88).
}

Como bem notou Paulo Motta Oliveira, no artigo "Rotas de papel: de cidades e províncias", nesse poema de Cesário há, também, "respostas a Antero" (OLIVEIRA, 2002, p. 249), ou, mais precisamente, à sua conferência. Em "Causas da decadência dos povos peninsulares nos últimos três séculos", é em nome do "progresso" que Antero quer dissolver todo o passado. A religião e o absolutismo estão na mesma perspectiva das navegações, o que faz com que ele volte seu olhar para Camões, vendo neste apenas o cantor de glórias que empobreciam os portugueses. No poema "O sentimento dum ocidental", Cesário reconhece a permanência nefasta do passado no presente, mas acrescenta a essa mesma perspectiva as consequências negativas do "progresso", praticamente as únicas que o Portugal de seu tempo experimentava e que se refletiam, sobretudo, na cidade (Lisboa). O contraponto estético para a opressão característica da Lisboa de seu tempo é buscado no passado glorioso de Portugal, cuja epopeia é escrita por Camões - o que faz com que Cesário volte seus olhos para a aventura portuguesa no mar, fonte da potência de um tempo "só de glórias feito". Oliveira 


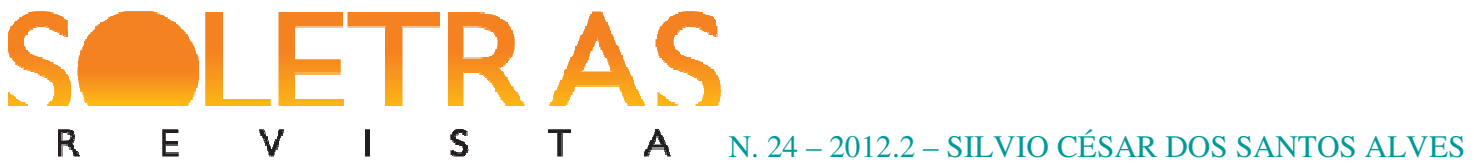

chama-nos a atenção para importantes coincidências e um contraste fundamental existentes entre a conferência de Antero e o poema de Cesário:

\begin{abstract}
"O sentimento dum ocidental", quando confrontado com "As causas da decadência dos povos peninsulares", e os próprios títulos possuem certos paralelismos e tensões interessantes, mostra-nos uma leitura totalmente outra seja do processo histórico, seja do presente. Ambos os textos configuram um presente apequenado, sufocante, problemático. Mas enquanto Antero canta a vinda de uma certa modernidade - por mais que revolucionária - como a forma de sanar os problemas presentes, e aproxima navegações, religião e absolutismo, Cesário separa esses termos. Os dois últimos, confinantes, são negativos, e como as causas de Antero, começam no passado e se perpetuam no presente. Mas, nesse mesmo presente, a cidade configura-se não só como o espaço em que religião e repressão se manifestam - pensemos nas patrulhas que partem dos quartéis que já foram conventos -, mas também como o equivalente semântico do progresso - não talvez o que se deseja, mas aquele que existe. Assim, numa leitura cerrada, progresso e religião, repressão e confinamento não se opõem, mas se complementam. No outro extremo, como saída desejada, mas não possível, temos o navegar, a recuperação das frotas dos avós e das vastidões aquáticas.

O que queremos sugerir é que o navegar, despido no período de Cesário de todo o poderio de que já havia possuído [...], converte-se, nas mãos desse poeta, em experiência de outra ordem. Em seus poemas tanto o campo - a malfadada província, sempre associada ao atraso e ao provincianismo - como o mar, espaço por excelência do contato com o outro, da busca e da descoberta - se conjugam ao amor e se transformam em símbolo daquilo que poderia ser - em outro tempo, em outra ordem - mas que o presente, citadino, obscuro e aprisionante, impede (OLIVEIRA, 2002, p. 256-257).
\end{abstract}

Cesário também não celebra Camões e o seu livro, mas vê aquele tempo da aventura marítima como um equivalente semântico para o campo, que, tendo sido um lugar comum em seus poemas anteriores a "O sentimento dum ocidental", só aparece nessa obra simbolizado através das "notas pastoris" de uma "longínqua flauta". Lembre-se que o campo aparece nos primeiros poemas de Cesário como significante da liberdade, em oposição à opressão significada pela cidade, mas à época d' "O sentimento dum ocidental" essa visão antinômica entre campo e cidade já estava em crise. Essa crise culminaria em "Nós", seu último poema publicado, com a revelação da inocência pueril que por trás dessa visão se escondia. Cesário parece, então, ter chegado à conclusão de que no mundo não há nenhum "Jardim do Amor" inatingível pelas injustiças que eram sempre atribuídas à vida urbana. Segundo Oliveira, "numa curiosa inversão de certos pressupostos presentes no raciocínio de Antero, Cesário tenderá a reavaliar não só o passado, mas os fantasmas do moderno que infestam seu cotidiano" (OLIVEIRA, 2002, p. 251). Carlos Reis afirma que essa "lembrança do passado 


\section{$\begin{array}{llllllll}\text { R } & \text { E } & \text { V } & \text { I } & \text { S } & \text { T } & \text { A } & \text { N. 24-2012.2-SILVIO CÉSAR DOS SANTOS ALVES }\end{array}$}

épico é claramente desencadeada pelo presente atrofiante" e que, "encarado como um tempo perdido, esse passado surge como imagem em contraste com um presente que se advinha de corrupção e decadência, anunciando um futuro também sombrio" (REIS, 2001, p. 405). Então:

Três séculos depois, este ocidental percorre o espaço de uma civilização industrial e urbana e reage emocionalmente a ela, confrontando amargamente o presente com um passado épico que é apenas a "memória quase perdida" de que fala Eça no final d'O Crime do Padre Amaro; daí, como se viu já, o contraste do "épico de outrora" com a vulgaridade de um "recinto público", "com bancos de namoro e exíguas pimenteiras" (REIS, 2001, p. 416).

Essa relação entre passado, presente e futuro, entre história e instante e sonho, que dinamiza "O sentimento dum ocidental", remete-nos, com efeito, à cena final d'O crime do padre Amaro, como aponta Carlos Reis, mas, também, à conferência de Antero, como indica Oliveira. Ao contrário de Antero, Cesário saberá aproveitar a simbologia da estátua de Camões e o sentido histórico comportado por ela - o das grandes navegações e das conquistas ultramarinas -, com vistas a empreender uma poderosa crítica de seu presente. Como Eça, Cesário retoma a "memória quase perdida" do passado épico português e, confrontando-a com seu tempo, revela-lhe a decadência em relação a esse passado. Mas, apesar dessa estratégia similar a do narrador queirosiano, o sujeito poético do poema "O sentimento dum ocidental" chega à conclusão de que a realidade por ele percebida não poderia ser pintada "Com versos magistrais, salubres e sinceros" (VERDE, 2003, p. 145). A análise positiva, feita com a "luneta de uma lente só" da ciência, revela-se incapaz para dizer-lhe qualquer coisa de sincero a respeito dessa realidade caótica, onde os larápios são ainda meninos, ao passo que as "Casas de confecções e modas resplandecem". Tal contexto requereria uma poética diferente daquela a que ele aspirava ao pretender compor um "livro que exacerbe". De certa forma, é nessa direção que o poema parece seguir.

Ao dizer que não é possível representar a realidade "com versos magistrais, salubres e sinceros", Cesário, além de deixar implícito que está a fazer outra coisa, parece, também, justificar-se em relação aos rumos que tomam os seus procedimentos poéticos. Ele deveras teria empreendido uma honesta tentativa no sentido de realizar uma representação sincera, positiva e objetiva da realidade. No entanto, essa tentativa ver-se-ia lograda por uma incongruência estrutural existente entre o objeto e o método. Cesário já havia dito que o que 


\section{$\begin{array}{llllllll}R & \text { E } & \text { V } & \text { I } & \text { S } & \text { T } & \text { A } & \text { N. 24-2012.2-SILVIO CÉSAR DOS SANTOS ALVES }\end{array}$}

lhe interessava era aquilo que estava à sua volta, afirmando, com isso, seu apego ao real, definindo o objeto de sua poesia. O problema, então, estaria no método, na fria análise que ele julgava compatível com a suposta sinceridade de versos pretensamente magistrais. De fato, o que Cesário faz com as orientações metapoéticas de "O sentimento dum ocidental" é tentar justificar o papel da síntese - que também não chega a realizar tal como prescrevia seu amigo Silva Pinto - e da imaginação que, na captação e representação de um real paradoxal e estilhaçado, esvaziado das antigas certezas e sem um fito que justifique as "longas descidas" da vida, põe em colapso toda a expectativa de realismo objetivo do flâneur. Logo, a conclusão de que "tudo cansa" e a necessidade de viver "eternamente", não só para alcançar a "perfeição das coisas", mas para que a sua própria busca faça sentido, acaba revelando o que, talvez, seja o verdadeiro sentimento do ocidental: o sentimento de total ausência de sentido da vida.

Para Annabela Rita, no artigo "O 'sentimento dum ocidental': um programa estético", a deambulação do sujeito poético de "O sentimento dum ocidental" revela "um percurso eminentemente reflexivo de um eu solitário em busca da sua identidade poética. Identidade que passa pela definição de um novo modelo literário, o seu" (RITA, 1992, p. 43). Margarida Vieira Mendes, em "Escrever-sobreviver", afirma que "ao contrário dos outros poemas, onde o sujeito em cena e em processo se afirma como poeta de um modo assertivo", em "O sentimento dum ocidental" Cesário "fá-lo num mundo hipotético e de pressuposições negativas: 'Quisera que o real e a análise mo dessem' e 'Não poder pintar com versos (...)" (MENDES, 1992, p. 49-50). Mendes afirma ainda que

Esta incapacidade de assunção do seu rosto de poeta, como centro organizador e cristalizador do mundo, conjuga-se com a dispersão e fragmentação que o próprio poema é e com a múltipla série de visões e de lembranças dadas por sensações poéticas confusas, sem a nitidez dos cinco sentidos. Sensações exageradas, quase alucinadas: os olhos "sangrentos" dum caleche", as "folhas das navalhas", os "gritos de socorro" (MENDES, 1992, p. 50).

Curioso é que o sujeito poético de "O sentimento dum ocidental" não raras vezes é comparado à personalidade do próprio Cesário Verde, como se esse poema fosse aquele em que o verdadeiro eu do poeta estivesse revelado. O que é certo é que, nessa obra, o sujeito poético empreende um movimento que tende a criar um paralelo entre os cacos do mundo que ele vê e o seu próprio eu estilhaçado, como numa espécie de mosaico revelador de seu sofrimento, mas não capaz de criar-lhe um "rosto". Quando falamos em "rosto" remetemos 
$\begin{array}{llllllll}\text { R } & \text { E } & \text { V } & \text { I } & \text { S } & \text { T } & \text { A } & \text { N. 24-2012.2-SILVIO CÉSAR DOS SANTOS ALVES }\end{array}$

àquela imagem que o homem tem de si mesmo como algo capaz de assegurar-lhe uma história, a história de seu próprio ser. Falamos dessa imagem capaz de representar-lhe socialmente, de assegurar-lhe uma identidade ideológica e servir-lhe como uma referência para que se lembre de si mesmo, tal qual a imagem que vemos refletida no espelho e nos olhos do outro. A assunção de uma tal espécie de "rosto" parece ter sido não só um problema para o Cesário que escreve "O sentimento dum ocidental", mas de todos os ocidentais que, no final do século XIX, percebiam-se desprovidos daquela antiga referência à "imagem e semelhança" da qual sabíamos ter sido feitos.

Com a perda daquela referência, em que o homem acreditava encontrar uma imagem e semelhança quase familiar e a esperança de um parentesco divino que o ligaria a uma totalidade garantidora de certos privilégios, perdeu-se, também, a validade de toda narrativa que, fundamentada nessa referência, apontava para uma meta, um mais além deste mundo, onde, decerto, estaria a "Verdade". Sozinho, sem um alvo e imerso em incertezas, como pode o homem assumir e manter tal rosto? Nesses tempos de incertezas, aos poucos, essa imagem foi se fragmentando e perdendo a capacidade de dizer algo sobre o que e quem se é.

Pensemos numa moeda com as suas faces já gastas pelo tempo e na dificuldade que teríamos para conferir-lhe um valor num tal estado. O século XIX ofereceu ao homem várias faces com as quais ele podia dar a si próprio um valor: liberalismo, socialismo, positivismo, republicanismo, catolicismo, misticismo... Com o passar do tempo, essas faces foram se desgastando, perdendo seu relevo. O homem finissecular, como uma moeda sem face, não sabia avaliar a si mesmo, como dar a si mesmo um valor, um rosto. Talvez, mais do que se identificar apenas a um "rosto", a uma imagem refletida no espelho e nos olhos do outro, a crise intelectual do fim de século tenha ensinado ao homem a importância de "ser o que se é", como bem notara Nietzsche em sua autobiografia Ecce Homo (NIETZSCHE, 2008, p. 38).

Sem deixar transparecer a matéria de que é feito, O Cesário de "O sentimento dum ocidental" é mesmo incapaz de assumir ou criar para si um "rosto de poeta" e impor-se "como centro organizador e cristalizador do mundo", de um mundo em ruínas. Quando se viu numa situação semelhante, experimentando o mais extremo niilismo e não tendo ainda condições de enfrentar o seu pensamento mais terrível, Nietzsche buscou forças em tipos, criou "espíritos livres” (NIETZSCHE, 1999, p. 64), companheiros que, nos momentos de convalescença, mantinham-no firme em sua "vontade saúde" (NIETZSCHE, 1999, p. 66), como nos conta em Humano, demasiado humano. É daí que surge o seu Zaratustra, dessa sua incapacidade em assumir um rosto, de ver-se no mesmo patamar daquela "nova espécie de filósofos" que, em 


\section{$\begin{array}{llllllll}\text { R } & \text { E } & \text { V } & \text { I } & \text { S } & \text { T } & \text { A } & \text { N. 24-2012.2-SILVIO CÉSAR DOS SANTOS ALVES }\end{array}$}

seu "ideal inverso", ele prevê em Para além de bem e mal (NIETZSCHE, 1999, p. 323), de posicionar-se como o "espírito criador" que, na "segunda dissertação" de Para a genealogia da moral, ele afirma ser "uma outra espécie de espíritos, do que, precisamente [no seu] século, são verossímeis" (NIETZSCHE, 1999, p. 355-356).

O surgimento de Zaratustra faz-nos lembrar o surgimento do "primeiro Fradique". Embora nascidos em momentos diferentes do século, não foram ambos resultantes de um “ideal inverso", anunciadores do por vir, rostos provisórios, fantasmas do futuro? O "último Fradique" surgiria com o mesmo propósito. E, embora o autor de "Memórias e notas" tivesse tentado, com aquela pseudobiografia, desenhar-lhe um rosto - ainda que muito eclético -, as suas iconoclastas correspondências tornariam a obra, que seria publicada postumamente em 1900, um verdadeiro paradoxo, tal qual o de Janus ${ }^{4}$.

É importante observar que entre o aparecimento do primeiro e do último Fradique ocorre o estabelecimento e a crise do positivismo ou do cientificismo como "atitude epistemológica socialmente orientada e com ecos seguros em Portugal" (REIS, 2000, p. 55). O Fradique de 69 surge ainda no rescaldo daquela intensa e eclética aquisição cultural proporcionada pelos caminhos de ferro aos jovens de Coimbra, enquanto o Fradique de 88 surgirá no crepúsculo das certezas da ciência e do positivismo, no crepúsculo daquilo que seu autor, assim como sua geração no início de suas atividades intelectuais, havia aprendido a denominar como a civilização ocidental.

No início de sua curta produção poética, compreendida num período de apologia da ciência e do progresso em Portugal, Cesário Verde, embora estivesse mais centrado no outro do que em si mesmo, não deixa de apresentar um rosto bem delineado em sua poesia: rosto de um poeta com um forte senso de justiça de origem proudhoniana, crítico da sociedade e da modernidade, mas crente num futuro de justiça, de saúde, de liberdade. Quando tudo isso se esvai, o que sobra? Nada! Mas é daí que saem suas duas obras-primas: "O sentimento dum ocidental" e "Nós". O fim desse último poema demonstra que, ao contrário de Nietzsche, Cesário não conseguira enfrentar e superar o pensamento mais terrível daquele fim de século: que tudo é sem sentido, que nada vale a pena.

Antero de Quental chegara cedo a essa conclusão. Se levarmos ao pé da letra as palavras

\footnotetext{
${ }^{4} \mathrm{Na}$ mitologia, Janus, ou Jano era o deus romano das portas e das passagens. Era representado como um corpo de duas faces: uma vigiando as entradas, a outra, as saídas. Suas faces opostas contemplariam, ao mesmo tempo, o dentro e o fora, o início e o fim, o passado e o futuro. Por ser o ponto de interseção entre o passado e o futuro, também representava o tempo presente. Ovídio chama-o de Caos, em As metamorfoses. O templo consagrado a este deus possuía duas portas opostas, fechadas em tempos de paz e abertas em tempos de guerra.
} 


\section{$\begin{array}{llllllll}\text { R } & \text { E } & \text { V } & \text { I } & \text { S } & \text { T } & \text { A } & \text { N. 24-2012.2-SILVIO CÉSAR DOS SANTOS ALVES }\end{array}$}

de António Sérgio, ele teria dois rostos bem definidos: um "noturno" e outro "luminoso". Esse rosto "noturno" que vemos, por vezes, aparecer em quase todas as suas obras, gerando nelas contradições importantes, será, por algum tempo, ofuscado pela luminosidade de seu outro rosto, o revolucionário, sem, no entanto, desaparecer totalmente. Mas, o claro sol, amigo dos heróis, não demorará a ser eclipsado pelo pessimismo - que, no Fradique de 69, havia se apresentado como satanismo. Proudhon, Hegel, Comte, Marx, Sidarta Gautama, Eckhart, o iberismo, nenhum deles puderam lhe assegurar um rosto confiável, capaz de sararlhe do "mal de ter nascido". O seu reconhecimento, de que era incapaz de assumir um "rosto" definitivo e ideal naquele século que terminava, pode ser visto na conhecida carta autobiográfica a W. Storck, em que ele vai enumerando, um a um, os diversos "fantasmas" nos quais buscara, em vão, apegar-se ao longo da vida. Há dois episódios dramáticos que nos remetem a essa incapacidade que Antero tinha para encontrar o tipo de rosto de que estamos falando, ou mesmo para encontrar-lhe alternativas: o primeiro ocorre quando ele destrói, por não conseguir concluir, a obra em relação a qual gerara tão grandes expectativas: Programa para os Trabalhos da Geração Nova. O segundo é quando, a 11 de setembro de 1891, ele suicida-se com dois disparos de revolver na boca, num banco encostado a um muro branco de convento, onde se lia a palavra "Esperança".

Ocorrido vinte anos após as "Conferências do Casino", o suicídio de Antero é um símbolo trágico das rápidas transformações culturais que esfarelavam as antigas certezas garantidas pela Razão - que haviam encontrado no Positivismo um último refúgio. $\mathrm{O}$ artigo Positivismo e Idealismo, de Eça de Queirós, surge, em 1893, como uma tentativa de ponderação dessas transformações. Mas seu autor demonstra-se incapaz de apontar um novo caminho que pudesse reestabelecer a segurança e a estabilidade ontológica em meio à radicalização das incertezas finisseculares. À altura em que escreve esse artigo, Eça não se encontra suficientemente incólume ante o naufrágio do mundo no qual se formara - e ao qual ajudara a conformar - para reconhecer, com nitidez, o quão longe já estava dele - e o quão perto se encontrava de algo por vir. Tanto aquilo que, nesse seu artigo, Eça aponta como uma conquista resultante da crise, quanto o que ele considera apenas como fatos de natureza transitória, configurariam aspectos do que hoje se conhece como a complexa visão de mundo pós-moderna. Talvez, por isso, por essa falta de nitidez para saber que caminho seguir em meio ao "nevoeiro", ele tenha deixado muitas de suas obras pelo caminho, até mesmo o Fradique de 88.

É claro que seria injusto esperar que Eça pudesse ter visto algo além do "nevoeiro". No 


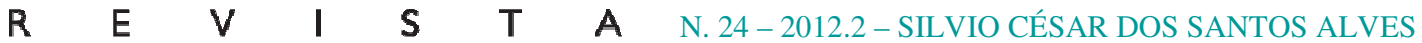

entanto, não se pode dizer que ele não tenha intuído o que estava além dele. É de Eça o trecho que se segue:

\begin{abstract}
Nunca mais ninguém, é certo, tendo fixo sobre si o olho rutilante e irônico da ciência, ousará acreditar que, das feridas que o cilício abria sobre o corpo de S. Francisco de Assis, brotavam rosas de divina fragrância. Mas também, nunca mais ninguém, com medo da ciência e das repreensões da fisiologia, duvidará em ir respirar, pela imaginação, e se for possível colher, as rosas brotadas do sangue do santo incomparável.

E isto é para nós, fazedores de prosa ou de verso, um positivo lucro e um grande alívio (QUEIRÓS, s/da, p. 1501).
\end{abstract}

O que Eça afirma, aí, é que nunca mais uma confiança incondicional levantar-se-ia sem a correlata pressuposição de uma desconfiança incondicional - paradoxo que caracterizaria essencialmente o século que ele não veria. Eça parece reconhecer que a contradição apresentada nesse trecho não era apenas um efeito positivo da crise, mas a essência mesmo daquilo que após ela se seguiria. Mas, de alguma forma, esse "paradoxo de Janus" ${ }^{5}$ parece têlo paralisado, pelo menos no que diz respeito às obras de maior fôlego, pois morre, em 1900, deixando vários romances não concluídos e outros de publicação abandonada ou interrompida.

Em "Noites de primavera no boulevard", um dos poemas escritos por Antero e atribuídos a Carlos Fradique Mendes, em 1869, o eu-poético, aparentemente impassível, acaba se deixando tomar pela "vertigem" de sua realidade caótica: "Sinto o terrível fluido... e vou, e vou, e vou.../E desejo e estremeço... e o delírio parece/Que me enche o coração, e a vida me endoidece!" (QUENTAL, 2001, p. 625). A vertigem serve ainda para revelar, num paradoxo muito semelhante ao trecho do artigo Positivismo e Idealismo que citamos anteriormente, aquilo que consideramos o toque de modernidade da poética do fradiquismo: “O mundo é artifício! - e, incerto, nem já sei/Se estes bicos de gás são realmente estrelas,/Ou só bicos de gás essas esferas belas!" (QUENTAL, 2001, p. 625). O segredo é o artifício, o efeito, a astúcia para fazer valer o falso num mundo esvaziado de verdades. O segredo é a descoberta de que a necessidade de verdade pode alimentar-se de falsidade. Mas até quando?

Para Hugo Fridrich, em Estrutura da lírica moderna: da metade do século XIX a meados do século $\mathrm{XX}$, Baudelaire foi, ao mesmo tempo, "o primeiro grande lírico do

\footnotetext{
${ }^{5}$ Esta expressão foi retirada do título do artigo Uma breve história do fim das certezas - ou o paradoxo de Janus, de Katja Plotz Fróis, que, no início de nossas pesquisas no Doutorado, serviu-nos de uma excelente fonte de estímulo.
} 


\section{$\begin{array}{llllllll}\text { R } & \text { E } & \text { V } & \text { I } & \text { S } & \text { T } & \text { A } & \text { N. 24-2012.2-SILVIO CÉSAR DOS SANTOS ALVES }\end{array}$}

modernismo" e "o primeiro teórico decisivo, na Europa, da lírica e do sentimento artístico modernos" (FREDRICH, 1978, p. 30). Uma das características da modernidade de Baudelaire apontadas por Friedrich é o que ele chama de "Despersonalização". Segundo esse autor, nenhuma das poesias baudelairianas poderia ser explicada, "em sua própria temática", "com a base de dados biográficos do poeta" (FRIEDRICH, 1978, p. 36).

Terá sido essa a verdadeira lição aprendida de Baudelaire pelos criadores de Carlos Fradique Mendes? A questão é que a despersonalização não é apenas um recurso estético, mas um fenômeno ontológico desde a "morte de Deus". O fim das verdades, a incapacidade de qualquer verdade para manter-se e fazer o homem suportar a sua vontade incondicionada de verdade, o medo humano de se deixar enganar, isso não é puro artifício, apesar de poder haver algum artifício, apesar de tudo se tornar artifício após a retirada das verdades absolutas.

Talvez, o mais importante no processo de mistificação levado a termo por Antero, Eça, e Jaime Batalha Reis, no final de 1860 - assim como nos ecos que esse processo encontraria em Cesário Verde e no Eça da maturidade -, tenha sido o seu papel na corrente de "desromantização" do romantismo, que tinha em Baudelaire a grande referência, na medida em que, da poética resultante dos processos fradiquianos e de suas ressonâncias, presume-se a impossibilidade de uma distinção objetiva entre a atitude confessional tipicamente romântica e o puro fingimento, que marcaria a literatura modernista.

\section{Referências bibliográficas:}

BERARDINELLI, Cleonice. Cesário entre Fradique e Sá-Carneiro. In: Convergência Lusíada: Revista do Real Gabinete Português de Leitura, Rio de Janeiro, n. 9, 1992, p. 11-24.

CATROGA, Fernando. Os inícios do Positivismo em Portugal. In: Revista de História das Ideias, s. 1, n. 1, 1976.

EIRAS, Pedro. Do dionisismo dândi: entre Fradique e Zaratustra. In: Revista da Faculdade de Letras: Línguas e Literaturas. Porto, II Série, v. XXI., 2004, pp. 101-142.

FERREIRA, Alberto. Estudos de cultura portuguesa do século XIX. Lisboa: Moraes, 1980.

FRANCHETTI, Paulo. Estudos de literatura brasileira e portuguesa. Cotia: Ateliê Editorial, 2007.

FRÓIS, Katja Plotz. Uma breve história do fim das certezas - ou o paradoxo de Janus. In.: Cadernos de Pesquisa Interdisciplinar em Ciências Humanas, Florianópolis, n. 63, UFSC, dezembro de 2004. 


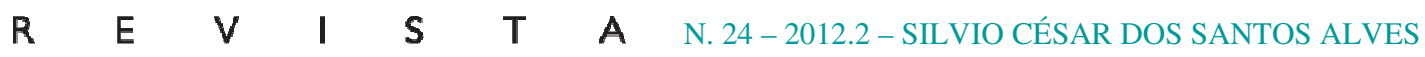

LIMA, Isabel Pires de. Os vencidos da vida: a consciência desistente. In: As máscaras do desengano. Lisboa: Editorial Caminho, 1987.

MATOS, Alfredo de Campos (Org.). Dicionário de Eça de Queiroz. 2. ed. Lisboa: Caminho, 1993.

MENDES, Margarida Vieira. Escrever-sobreviver. "Apresentação crítica". In: VERDE, Cesário. Poesias de Cesário Verde. Lisboa: Editorial Comunicação, 1992.

MOURÃO-FERREIRA, David. Sobre o decassílabo e o alexandrino na poesia de Cesário Verde. In: Colóquio Letras: volume especial sobre Cesário Verde. Lisboa, Fundação Calouste Gulbenkiam, n. 93, set. 1986, p. 74-81.

MOURÃO-FERREIRA, David. Cesário e Camões: uma leitura complementar de "O sentimento dum ocidental”. In: Colóquio/Letras, Lisboa, Fundação Calouste Gulbenkiam, n. 135-136, jan. 1995, p. 83-94.

NIETZSCHE, Friedrich. Assim falou Zaratustra. Petrópolis, RJ: Vozes, 2007.

. Ecce Homo. Covilhã, PT: Universidade da Beira Interior, 2008.

Obras incompletas: Humano, demasiado humano; Para além de bem e mal; Para a genealogia da moral. São Paulo: Nova Cultural, 1999 (Os Pensadores).

OLIVEIRA, Paulo Motta. Rotas de papel: de cidades e províncias. In.: Semear 6. Revista da Cátedra Padre António Vieira de Estudos Portugueses, Petrópolis, RJ, Vozes, 2002.

QUEIRÓS, Eça de. Obras de Eça de Queirós. Volume II. Porto: Lello \& Irmão Editores, s/da. O crime do padre Amaro. Rio de janeiro: Ediouro, s/db. Os Maias. São Paulo: Editora Nova Alexandria, 2000.

QUENTAL, Antero de. Odes modernas. Coimbra: Imprensa da Universidade, 1865. 1926. Causas da decadência dos povos peninsulares. In.: Prosas: Vol. II. Coimbra, s/ed., Poesia completa: 1842-1891. Lisboa: Publicações Dom Quixote, 2001.

REIS, Carlos. As Conferências do Casino. Lisboa: Publicações Alfa, Testemunhos Contemporâneos, 1990.

Estudos queirosianos: ensaios sobre Eça de Queirós e a sua obra. Lisboa: Editorial Presença, 1999.

2001. (Org). História da Literatura Portuguesa: O Realismo e o Naturalismo. Lisboa: Alfa, 


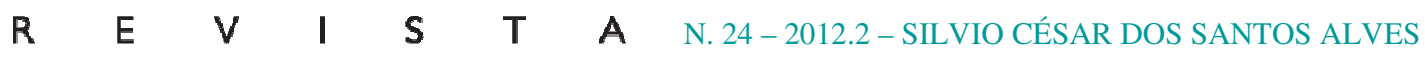

Introdução. In: $O$ crime do padre Amaro (Edição crítica das obras de Eça de Queirós). Lisboa: Imprensa Nacional-Casa da Moeda, 2000.

REIS, J. Batalha. Anos de Lisboa: algumas lembranças. In: Anthero de Quental/In Memoriam. Porto: Mathieu Lugan, 1896.

RITA, Annabella. “O sentimento dum ocidental”: um programa estético. In: Colóquio/Letras, Lisboa, Fundação Calouste Gulbenkiam, n. 125-126, jul. 1992, p. 43-46.

SERRÃO, Joel. Gênese e descendência da poesia de Cesário Verde. In: Cesário Verde: Comemorações do centenário da morte do poeta. Compilação das comunicações apresentadas no Colóquio sobre Cesário Verde realizado, em colaboração com a Secretaria de Estado da Cultura, na Sala Polivalente do Centro de Arte Moderna em outubro de 1986, Lisboa, Fundação Calouste Gulbenkian, 1993, pp. 81-88.

O primeiro Fradique Mendes. Lisboa: Livros Horizonte, 1985.

SILVEIRA, Jorge Fernandes. Camões, Cesário Verde e o coro. In: Convergência Lusíada: Revista do Centro de Estudos do Real Gabinete Português de Leitura, Rio de Janeiro, ano IV, n. $7,1979-1980$, p. 125-133.

SÉRGIO, António. Nota preliminar aos Sonetos. In: QUENTAL, Antero de. Sonetos. Lisboa: Sá da Costa, 1962.

VERDE, Cesário. Obra completa de Cesário Verde. 8. ed. Lisboa: Livros Horizontes, 2003.

WEISSTEIN, Ulrich. Literatura Comparada: definição. In: COUTINHO, Eduardo; CARVALHAL, Tânia Franco (Orgs.). Literatura Comparada: textos fundadores. Rio de Janeiro: Rocco, 1994, pp. 308-333.

\title{
Some heralds of modernity: Cesário Verde, Antero de Quental, Eça de Queirós and the intellectual crisis in Portugal at the end of the 19th Century
}

\begin{abstract}
This paper aims at presenting some aspects of the relationship between Cesario Verde, Antero de Quental, Eca de Queiroz, and their works, with the intellectual crisis of the 19th century. We try to point out the extent to which these authors were or not able to overcome the end of the certainties in Western Culture in the middle of this century. Above all, we seek to reveal in these authors, aesthetics procedures that announce new values that later would be identified with Portuguese modernity.
\end{abstract}

Key words: Portuguese Literature. Intellectual crisis. 19th century.

Recebido em: 15 de junho de 2012

Aprovado em: 20 de dezembro de 2012. 